\title{
The Economics of Europe
}


By the same author

THE PROBLEM OF THE NATIONAL DEBT

THE MECHANISM OF CHEAP MONEY

THE SOCIAL ACCOUNTS OF THE WELSH ECONOMY (ed.)

TEXTBOOK OF ECONOMIC ANALYSIS*

CAPITAL FUNDS IN UNDERDEVELOPED COUNTRIES*

A WORKBOOK OF ECONOMIC ANALYSIS*

THE STRUCTURE OF THE WELSH ECONOMY (ed.)

THE LONDON CLEARING BANKS (with E. W. Davis)

REGIONAL POLICY AND THE ROLE OF BANKING

AN INTRODUCTION TO MICROECONOMICS

THE ECONOMICS OF DEVOLUTION (ed.) 


\title{
The Economics of Europe
}

\author{
Edward Nevin
}

Emeritus Professor of Economics

University College of Swansea

Macmillan Education 
ISBN 978-0-333-51632-4 ISBN 978-1-349-20923-1 (eBook)

DOI 10.1007/978-1-349-20923-1

(C) Edward Nevin 1990

Softcover reprint of the hardcover 1st edition 1990

All rights reserved. For information, write:

Scholarly and Reference Division,

St. Martin's Press, Inc., 175 Fifth Avenue,

New York, N.Y. 10010

First published in the United States of America in 1990

ISBN 978-0-312-04744-3

Library of Congress Cataloging-in-Publication Data

Nevin, Edward.

The economics of Europe / Edward Nevin.

p. $\mathrm{cm}$.

ISBN 978-0-312-04744-3

1. European Economic Community. 2. European Economic Community

Great Britain. 3. Europe-Economic integration. I. Title.

HC241.2.N485 1990

$330.94-\mathrm{dc} 20$ 


\section{Contents}

List of Tables and Figures

vii

Preface

List of Abbeviations

ix

xi

PART I THE FRAMEWORK

1 In the Beginning

2 Britain and Europe

3 The Evolving Community

4 Institutions: Council and Court 31

5 Institutions: Commission and Parliament 42

PART II THE THEORY OF ECONOMIC INTEGRATION

6 The Economics of Integration

7 Trade Creation and Trade Diversion 64

8 Scale and Externalities $\quad 76$

9 Terms of Trade and Dynamic Effects $\quad 87$

10 Testing the Theory 98

11 The Impact on Britain 109

\section{PART III MICROECONOMIC POLICIES}

12 Competition Policy

13 Industrial Policy

14 The Birth of the Common Agricultural Policy 146

15 The Life of the Common Agricultural Policy

16 The Common Fisheries Policy

17 Transport Policy

18 Energy Policy

19 Social and Environmental Policy

20 Tax Harmonisation 
vi Contents

\section{PART IV MACROECONOMIC POLICIES}

21 The Community Budget

22 European Monetary Union - The Theory 255

23 The European Monetary System 269

24 Regional Policy 287

25 Commercial Policy - Friends and Neighbours 303

26 Commercial Policy - The World at Large 316

PART V CONCLUSION

271992 and All That

Statistical Appendix

Author Index

356

Subject Index 


\section{List of Tables and Figures}

\section{Tables}

2.1 Merchandise Trade of the United Kingdom, 1935-88 15

3.1 The Community of Twelve, $1986 \quad 26$

4.1 Council of Ministers: Voting Allocations 34

5.1 The European Parliament, 1958-89 48

9.1 The Impact of Dynamic Gains 93

10.1 The Static Trade Effects of the EEC 101

10.2 The Dynamic Effects of European Integration 107

11.1 UK Static Gains and Losses from EC Membership, $1980 \quad 109$

11.2 UK Balance of Payments with the EC, 1973-83 112

15.1 Agriculture in the European Community, 1958-86 161

15.2 Annual Benefits and Costs of the CAP, 1984 169

16.1 Fishing in the European Community, 1958-81 181

17.1 Transport in the European Community, 1981

18.1 Energy in the European Community, 1958-86 206

18.2 Energy Import-dependence in the European Community 208

19.1 The European Social Fund, 1960-88 213

20.1 Turnover Tax vs. Value Added Tax 226

20.2 VAT Rates in the European Community, January $1988 \quad 228$

20.3 Excise Duties in the European Community, 1987

21.1 The General Budget of the European Community, 1958-88 245

21.2 Net EC Budgetary Contributions, 1976-86 251

21.3 The Fontainebleau Mechanism 253

23.1 The Composition of the ECU 275

23.2 Central ECU Rates, 1979-89 279

23.3 The Performance of the EMS, 1979-84 280

24.1 Regional Variances in the European Community, 1950-82 292

24.2 Quotas in the European Regional Development Fund 295

24.3 Grants from the ERDF, 1975-88 297

25.1 ACP Trade with the EC 9, 1963-79 308 
25.2 EFTA Trade with the EC 9, 1963-79

25.3 Maghreb/Mashreq Trade with the EC 9, 1963-79 314

26.1 The Community's Trade with the World, 1958-85

\section{Figures}

6.1 The Deadweight Loss of a Tax 58

7.1 A No-trade Pre-entry Customs Union 67

$\begin{array}{lll}7.2 & \text { A Low-tariff Union } & 70\end{array}$

$\begin{array}{lll}7.3 & \text { A High-tariff Union } & 73\end{array}$

8.1 Pure Trade Creation 78

$\begin{array}{lll}\text { 8.2 Trade Creation and Trade Diversion } & 79\end{array}$

$\begin{array}{lll}8.3 & \text { Trade Suppression } & 80\end{array}$

$\begin{array}{lll}8.4 & \text { A Sub-optimal Outcome } & 81\end{array}$

8.5 The Subsidy System and the Tariff System 85

9.1 The Optimum Tariff $\quad 88$

9.2 A Customs Union and the Terms of Trade 90

9.3 Incidence of a Tax 96

14.1 The Cobweb Phenomenon 149

14.2 The CAP Price-support System 153

22.1 Unemployment and Inflation 260

22.2(a) Balance-of-payments Equilibrium: the Keynesian View 263

22.2(b) Monetary Union: the Keynesian View 264

22.2(c) Monetary Union: the Monetarist View 265 


\section{Preface}

A commercial advertisement appearing in 1988 described the European Community as 'six republics, five Kingdoms and one Grand Duchy separated by nine languages'. The description was not entirely serious but neither could it be described as entirely meaningless. To the outside observer the Community frequently presents itself as a complex, remote and not entirely credible organisation, inhabited by politicians and bureaucrats but having little bearing on the daily life of the ordinary citizen. Nowhere is this attitude of faint disbelief more widely held than in the United Kingdom. Yet the facts are that for those of us who dwell in Western Europe it is part of our lives and we, in turn, form part of it. Its structure, operation and objectives therefore have become matters deserving of systematic study throughout the educational system and beyond. This book is an attempt to provide a beginner's guide to that process.

In writing such a book there is one insoluble problem: what prior knowledge of what subject can safely be assumed in the reader? It is not a question of answering the question successfully: rather it is one of answering it wrongly to the least possible degree. Since I am primarily concerned with the economic aspects of the European Community, the problem essentially reduces to one of the extent to which the reader can be assumed to be familiar with the basic analytical concepts and constructs of economics. To assume no knowledge whatever would imply a need to indulge in a detailed explanation of almost every basic principle of economics; such a procedure would result in a book whose length would be exceeded only by the tedium it would induce in those to whom the interaction of demand and supply is not entirely a theological mystery. To assume graduate standing in economics, on the other hand, would lead to a work which would be totally unintelligible to the great majority of its potential readers. Compromising, then, I have assumed, roughly speaking, a prior knowledge of economics broadly comparable with that of a first-year university course or perhaps a good Advanced Level grade in the subject. Those better equipped in economics must exercise charity and bear with what will frequently seem an unduly simplified and elementary treatment of some quite sophisticated theoretical problems; those less well equipped may have to take 
some of the theoretical propositioins on trust and may, indeed, skip Part II altogether.

The book is written with an eye rather firmly fixed on the reader resident in, and concerned with, the United Kingdom. I hope nevertheless that it has not as a result become so introspective as to lose sight of the essentially supranational character of the Community. Residents of Northern Ireland will forgive me, I hope, for having frequently used the terms 'Britain' and 'British' as synonymous with the terms 'United Kingdom of Great Britain and Northern Ireland' and 'citizen of ...' in order to avoid both undue verbosity and the monotony of repetition. I have also tended to use the term 'European Community' in preference to the awkward but none the less legally correct expression 'European Communities'. Less defensibly, again in the interests of brevity and the avoidance of repetition, I have frequently used the word 'Europe' to refer to the Community where the context does not allow of misunderstanding; I have even used the term 'Mediterranean' to include Portugal. I trust these lapses in geographical accuracy will not irritate overmuch.

Finally, a word should be said about the frequent (and unavoidable) references to monetary magnitudes throughout the book. Since the magnitudes concerned normally involve more than one country they are usually expressed in terms of the European Currency Unit (ECU), despite the undoubted fact that no such currency unit existed prior to 1979. For years prior to 1979 national currency units have been converted into ECUs at their prevailing exchange rates and using the weights given to each currency in 1979 when the ECU was first created. Furthermore, to use contemporary monetary values for events stretching over thirty years would clearly result in figures of little comparative meaning. Unless stated otherwise, therefore, all monetary values have been converted into their equivalents at 1986 prices in order that a sum quoted for, say, 1960 can be compared meaningfully with the corresponding sum for 1980. (This has the convenient result that the sums quoted in ECUs may be taken as equivalent to the same sum in US dollars, a currency unit which still has more meaning than the ECU for most of us; the average rate of exchange of ECUs for dollars in 1986 was almost exactly one.) For similar reasons the national income figures used throughout are those based on the Commission's estimates of the comparative purchasing-powers of various currencies, rather than those based on current exchange rates. There are good arguments for using each of these bases of comparison, but for the purposes of this book I feel that exchange rate instability - especially that of the 1970 s - renders national income comparisons based on current exchange rates seriously misleading. The Statistical Appendix contains the data necessary to convert values into current prices in dollars, based on prevailing exchange rates, should any reader feel a compulsive preference for such valuations. 


\section{List of Abbreviations}

\begin{tabular}{|c|c|}
\hline AASM & Associated African States and Malagasy \\
\hline ACP & African, Caribbean and Pacific States \\
\hline BENELUX & Belgium-Netherlands-Luxembourg Economic Union \\
\hline BN. & Billion $\left(10^{6}\right)$ \\
\hline BRITE & Basic research in industrial technologies for Europe \\
\hline CAP & Common agricultural policy \\
\hline CFP & Common fisheries policy \\
\hline COREPER & Committee of Permanent Representatives \\
\hline DG & Directorate-General \\
\hline DM & Deutschemark \\
\hline EC & European Communities \\
\hline ECSC & European Coal and Steel Community \\
\hline ECU & European Currency Unit \\
\hline EDF & European Development Fund \\
\hline EEC & European Economic Community \\
\hline EEIG & European Economic Interest Grouping \\
\hline EEZ & Exclusive Economic Zone \\
\hline EFTA & European Free Trade Association \\
\hline EIB & European Investment Bank \\
\hline EMS & European Monetary System \\
\hline ERDF & European Regional Development Fund \\
\hline ESF & European Social Fund \\
\hline ESPRIT & $\begin{array}{l}\text { European strategic programme for research and development } \\
\text { in information technology }\end{array}$ \\
\hline EURATOM & European Atomic Energy Community \\
\hline FECOM & European Monetary Co-operation Fund \\
\hline FEOGA & European Agricultural Guidance and Guarantee Fund \\
\hline FR & Franc \\
\hline GATT & General Agreement on Tariffs and Trade \\
\hline GDP & Gross domestic product \\
\hline GNP & Gross national product \\
\hline
\end{tabular}




$\begin{array}{ll}\text { GSP } & \text { Generalised system of preferences } \\ \text { GWh } & \text { Gigawatt hour }\left(10^{6} \text { kilowatt hours }\right) \\ \text { IEA } & \text { International Energy Agency } \\ \text { IMF } & \text { International Monetary Fund } \\ \text { IMP } & \text { Integrated Mediterranean Programmes } \\ \text { JET } & \text { Joint European Torus } \\ \text { MCA } & \text { Monetary Compensatory Amount } \\ \text { MFA } & \text { Multifibre Arrangement } \\ \text { NATO } & \text { North Atlantic Treaty Organisation } \\ \text { NTB } & \text { Non-tariff barrier } \\ \text { OECD } & \text { Organisation for Economic Co-operation and Development } \\ \text { OEEC } & \text { Organisation for European Economic Co-operation } \\ \text { OPEC } & \text { Organisation of Petroleum Exporting Countries } \\ \text { RACE } & \text { Research and development in advanced communication } \\ & \text { technologies for Europe } \\ \text { STABEX } & \text { System for the stabilisation of export earnings } \\ \text { SYSMIN } & \text { System for financing mining products } \\ \text { TAC } & \text { Total allowable catch } \\ \text { UK } & \text { United Kingdom of Great Britain and Northern Ireland } \\ \text { UN } & \text { United Nations } \\ \text { UNCTAD } & \text { United Nations Conference on Trade and Development } \\ \text { US } & \text { United States of America } \\ \text { VAT } & \text { Value added tax } \\ \text { VER } & \text { Voluntary export restraint }\end{array}$

